\title{
Virtual industrial water usage and wastewater generation in the Middle East and North Africa 2011-2015
}

\author{
Simon R. Sakhel ${ }^{1} \cdot$ Sven-Uwe Geissen $^{2} \cdot$ Alfons Vogelpohl $^{1}$
}

Received: 6 June 2016/ Accepted: 7 March 2017/Published online: 21 March 2017

(C) Springer International Publishing Switzerland 2017

\begin{abstract}
This study presents useful methods for quantifying the volumes of water usage, wastewater generation, virtual water export, and wastewater generated by export for six relevant export industries in the Middle East and North Africa (MENA) region. These export industries are based in: Algeria, Bahrain, Egypt, Iran, Iraq, Israel, Jordan, Kuwait, Lebanon, Libya, Morocco, Oman, Palestinian Territories, Qatar, Saudi Arabia, Syria, Tunisia, and United Arab Emirates (UAE). Results show that approximately $4.26 \times 10^{9} \mathrm{~m}^{3}$ of water is used per annum and approximately $1.04 \times 10^{9} \mathrm{~m}^{3}$ of wastewater is generated during production by the studied industries in 2011. The difference $\left(3.22 \times 10^{9} \mathrm{~m}^{3}\right)$ between the used water and
\end{abstract}

Electronic supplementary material The online version of this article (doi:10.1007/s41207-017-0018-9) contains supplementary material, which is available to authorized users.

Simon R. Sakhel

simonsakhel@hotmail.com

Sven-Uwe Geissen

sven.geissen@tu-berlin.de

Alfons Vogelpohl

vogelpohl@itv.tu-clausthal.de

1 Institut fuer Thermische Verfahrens-und Prozesstechnik, Technische Universitaet Clausthal, Leibnizstrasse 15, 38678 Clausthal-Zellerfeld, Germany

2 Institut fuer Technischen Umweltschutz, Technische Universitaet Berlin, FG Umweltverfahrenstechnik, Strasse des 17 Juni 135, 10623 Berlin, Germany generated wastewater volumes is related to water evaporation or injection underground (oil well pressure maintenance). The net virtual water export of the six studied commodities for the year 2015 from MENA to EU28 [i.e., 28 countries in the European Union] is approximately $3.0 \times 10^{8} \mathrm{~m}^{3}$, which is equivalent to approximately $7.05 \%$ of the water used by those industries. For example, Saudi Arabia represents the largest net virtual water exporter (approximately $1.25 \times 10^{8} \mathrm{~m}^{3}$ ). Crude oil represents approximately $2.59 \times 10^{8} \mathrm{~m}^{3}$ of the net virtual water export; fertilizers represent $6.5 \times 10^{7} \mathrm{~m}^{3}$, while pig iron and olive oil represent $3.9 \times 10^{5}$, and $1.3 \times 10^{5} \mathrm{~m}^{3}$, respectively. The Saudi Arabian hydrological system is under the greatest pressure externally due to these exports to EU28, where the net virtual water export represents approximately $1.6 \%$ of the actual renewable water resources and desalination capacity of this country. In general, this study shows that, in terms of the grey water footprint (GWF), the pollution of water bodies caused by production (year 2011) is relevant for the crude oil, refined petroleum, and olive oil industries, whereas pollution caused by exports to EU28 countries (year 2015) is primarily related to the crude oil industry and olive oil mills. The GWFs for all the six industries caused by production and export are $111.8 \times 10^{9}$ (for the year 2011) and $18.7 \times 10^{9} \mathrm{~m}^{3} /$ year (for the year 2015), respectively. One importance of the current work is that the specific water uses here could be compared to those of the same industries in developed countries. Based on these comparisons, decisions related to the need for water conservation can be made. The implementation of industrial water conservation in the MENA region could alleviate the pressure on water resources and help mitigate the water problems in the MENA. The time in which these 
results apply for production and export are the years 2011 and 2015 , respectively.

Keywords Water usage - Wastewater generation - Virtual water export - Wastewater generated by export - MENA, EU28

\section{Introduction}

The region of the Middle East and North Africa (MENA) is the most water-scarce region in the world (World Bank 2012). In this region, including Malta and excluding Djibouti (MexcD), less than $1 \%$ of the world's renewable freshwater is available (Khedr 2006). The demand for water there began to exceed the supply in the early 1970s. For example, in Egypt, the demand is $25 \%$ higher than the available water resources, and the gap is satisfied by recycling agricultural drainage water and trapping water losses (Gad and Ali 2009). In the Kingdom of Saudi Arabia, the water deficit has been reported as unresolved in 1999 (Hong 2004), and the demand is largely satisfied through groundwater resources, through desalinizing seawater and recycling of treated wastewater used for agriculture and industry (Abderrahman 2009).

Furthermore, certain countries of MENA (MexcD) have adequate quantities of renewable water resources, whereas others have low levels. The supply of urban water is intermittent in most of the cities of the latter region and particularly noticeable in the summer, when the municipal water is pumped to households only once or twice a week and turned off otherwise. There are 45 million people in this region that still lack adequate access to safe drinking water (Khedr 2006).

Water scarcity is linked to an important term to the present research namely "virtual water" (VW) that has been introduced by (Allan 1993). In that sense, it has been found that VW trade may curb the negative effects of water scarcity (Roson and Sartori 2010) and another study found that inverting VW flows could be a solution for alleviating this problem in central Asia (Porkka 2011). The countries that are water scarce should import commodities that are water intensive and export commodities that require much less water for its production. Doing that helps in alleviating this problem. This is why VW is a term that can be used to achieve an objective distribution of water resources around the world and it is vital to estimate virtual water flows into and out of the MENA region.

The VW term is also related to the water footprint (WF) that has been introduced by Hoekstra in 2003. For example, $\mathrm{VW}$ is used in the calculation of the water footprint of nations where the VW exported and imported by the nation is used in this calculation. There have been substantial efforts to quantify the VW flows between nations in recent years (Hoekstra and Hung 2002; Chapagain and Hoekstra 2003, 2004; Zimmer and Renault 2003; Oki et al. 2003). The first attempt on an international level was performed by Hoekstra and Hung (2002), and several studies were subsequently conducted on global VW flows related to international trade (food and non-food commodities), global WFs, and VW flows related to the trade of five crops and three livestock products (Chapagain and Hoekstra 2004; Zhan-Ming and Chen 2013; Hanasaki et al. 2010). The industrial VW flows and WFs of all nations have also been estimated (Hoekstra and Mekonnen 2012). For example, the VW flows related to the Spanish international grain trade ranged between 3420 and 8415 million $\mathrm{m}^{3}$ in the years 1997-2005 (Novo et al. 2009). Andalusian crop net VW import within Spain has been estimated as 1377 million $\mathrm{m}^{3}$ for the year 2002 (Velázquez 2007). Moreover, agricultural product trade between the Nile basin states and the rest of the world showed an annual net virtual water import of 27,000 million $\mathrm{m}^{3}$ in the period from 1998 to 2004 (Zeitoun et al. 2010). VW flows within India and China have also been estimated. Regarding India, the mean annual inter-state VW trade in crops is 106,000 million $\mathrm{m}^{3}$ for the years 1997-2001 (Verma et al. 2009), while China's northern and southern parts have been found to be a net virtual water exporter [having a value of 4225.4 million $\mathrm{m}^{3}$ (year 1997)] and net virtual water importer [having a value of 148.1 million $\mathrm{m}^{3}$ (year 1997)], respectively (Guan and Hubacek 2007). There have also been efforts to estimate the WFs of products, cities, countries, regions, and processes (Van Oel and Hoekstra 2012; Mekonnen and Hoekstra 2012a, b; Ercin et al. 2012; Gerbens-Leenes and Hoekstra 2012; Jefferies et al. 2012; Ruini et al. 2013; Zhang et al. 2011; Chapagain and Hoekstra 2011; Dong et al. 2013; Vanham and Bidoglio 2013; Van Oel et al. 2009; Niccolucci et al. 2011). For example, Chapagain and Hoekstra (2011) estimated the global water footprint of rice production as 784,000 million $\mathrm{m}^{3} /$ year in the period from 2000 to 2004. Zhang et al. (2011) estimated the water footprint of Beijing in 2002 as 4498.4 million $\mathrm{m}^{3} /$ year, while Van Oel et al. (2009) estimated the water footprint of the Netherlands as $2300 \mathrm{~m}^{3} / \mathrm{cap} / \mathrm{year}$ for the period 1996-2005. Finally, Dong et al. (2013) estimated the water footprint of Liaoning in 2007 as 7300 million $\mathrm{m}^{3}$. However, published reports are not available on the net VW export through the trade of potash, fertilizers, crude oil, refined petroleum, olive oil, and pig iron to the 28 countries of the European Union (EU28) (2016), especially from the MENA region.

The goal of this paper is to quantitatively assess the volumes of water usage, generated wastewater, VW 
exported to EU28, and wastewater generated by export (WWGE) for six export-relevant industries of MENA. These export industries are based in: Algeria, Bahrain, Egypt, Iran, Iraq, Israel, Jordan, Kuwait, Lebanon, Libya, Morocco, Oman, Palestinian Territories, Qatar, Saudi Arabia, Syria, Tunisia, and United Arab Emirates (UAE). Production data in this study are for the year 2011 and those for export are 2015. The production data are all for the year 2011 due to the unavailability of complete fertilizer production data for the relevant countries after that year. The estimated industrial water use volumes can be divided by the weights of the products of each specific industry, thus resulting in specific water uses that can be compared to those of the same industries in developed countries. Based on these comparisons, decisions related to the need for water conservation can be made. The implementation of industrial water conservation in the MENA region could alleviate the pressure on water resources and help mitigate the corresponding problems in the region. Reducing the specific amount of water used for production will also affect the virtual industrial water use volume of the EU28. This will lead to a reduction of this use, and it will also help mitigate the related problems in the MENA region. Moreover, we aim to estimate the volume of industrial grey water flows, which provide important contributions to the design and construction of treatment plants for MENA industries. These are also important because of their potential for pollution and the cost of environmental repair. For example, certain MENA industries, such as the olive oil industry, do not have treatment plants; consequently, determining wastewater volumes will assist in the future design of these plants.

Another goal is to shed light on the industries that are the most relevant in terms of pollution caused by production and export through calculating their grey water footprint (GWF) and determining their indirect water consumption by EU28 through the import of goods from the MENA region.

In summary, this study aims to quantify and evaluate the indirect pressure that EU28 poses on the hydrological systems of the MENA region. In "Important terms and rationales for selecting the industries studied in this work", we define important terms and identify our reasons for selecting the industries studied in this work. "Methodology and assumptions" presents a summary of the methodology and assumptions used for the calculations. "Results and interpretations" displays the results and interpretations. In "Discussion", we discuss the results, and in "Conclusions", we end with conclusions.

\section{Important terms and rationales for selecting the industries studied in this work}

\section{Definition of important terms}

VW: Water that is required to produce agricultural or industrial goods

WF: Indicator of freshwater use considers direct and indirect water use; the WF is a volumetric measure of water consumption and pollution (Hoekstra et al. 2011)

\section{Water use}

1. For the fertilizer and refining industries, water use represents water that is consumed through evaporation and released as wastewater.

2. For the crude oil industry, water use represents water that is injected underground and used to wash crude oil.

3. For potash and olive oil industries, water use represents water that is released as wastewater.

4. For all industries, water use represents water that is withdrawn either from the surface, ground, or sea.

\section{GWF}

The volume of freshwater required to assimilate the load of pollutants which is based on natural background concentrations and ambient water quality standards (Hoekstra et al. 2011).

\section{MENA (World Bank2 2017)}

The region that includes the following countries: Algeria, Bahrain, Djibouti, Egypt, Iran, Iraq, Israel, Jordan, Kuwait, Lebanon, Libya, Morocco, Oman, Palestinian Territories, Qatar, Saudi Arabia, Syria, Tunisia, United Arab Emirates (UAE), and Yemen.

\section{Actual renewable water resources}

The sum of internal renewable water resources (average fresh water resources renewably available over a year from precipitation falling within a country's borders) and external renewable water resources which is the country's renewable water resources that enter from upstream countries through rivers (external surface water) or aquifers (external groundwater resources) (Food and Agriculture Organization of the United Nations FAO 2003). 


\section{EU28 (European Union)}

the union that includes the following countries: Austria, Belgium, Bulgaria, Croatia, Cyprus, Czech Republic, Denmark, Estonia, Finland, France, Germany, Greece, Hungary, Ireland, Italy, Latvia, Lithuania, Luxembourg, Malta, Netherlands, Poland, Portugal, Romania, Slovakia, Slovenia, Spain, Sweden, and United Kingdom (U.K).

\section{Rationales for selecting the industries studied in this work}

The six export-relevant industries that are considered include crude oil (based in: Algeria, Egypt, Iran, Iraq, Kuwait, Libya, Oman, Qatar, Saudi Arabia, Tunisia, and UAE), refined petroleum (based in: Algeria, Bahrain, Egypt, Iran, Iraq, Israel, Kuwait, Libya, Morocco, Oman, Qatar, Saudi Arabia, Tunisia, and UAE), fertilizer (based in: Algeria, Egypt, Iran, Israel, Kuwait, Lebanon, Libya, Morocco, Saudi Arabia, Syria, Tunisia, and UAE), pig iron (based in Algeria), potash (based in: Israel and Jordan), and olive oil (based in: Algeria, Egypt, Israel, Lebanon, Morocco, Palestinian Territories, Syria, and Tunisia). The first five of these industries were selected, because they are considered to be major industries (Shaikh Al-Deen and ElKholy 2001; CIA The World Factbook 2015; The Report: Emerging Algeria 2008; Yager 2005; Mobbs 2005a). An industry is classified as 'major' based on several factors, such as its contribution to gross domestic product (GDP), the percentage of the population it employs, and its gross business receipts (Economy Watch 2010). These three economic indicators show the importance of the first five industries listed above. The major industry of a country is classified after ranking all the country's industries according to their contributions to the GDP and the percentage of the population they employ. The industries at the top of the list are the major industries [According to D. Clark (personal communication, 15 Jan 2011) and J. Biddle (personal communication, 13 January 2011)].

Table 1 shows the percentage contribution of the five major industries to the total GDP of a country and the total export income, whereas Table 2 shows the percentage contribution to GDP and percentage share of the total export income, the relative water use to other industries, and the relative pollution in terms of biological oxygen demand (BOD) to the pollution of the textile industry. These industries provide a considerable contribution to GDP and the export income. The water use is 0.3- to 45.9fold higher than that of other industries, and the pollution potential is 0.1 - to 1.3 -fold higher than that of the textile industry; thus, the water use and pollution potential are considerable.

The selection of the olive oil industry can be justified economically and environmentally. The olive sector in

Table 1 Range of percentage contribution to the total GDP and export income for the five major industries in MENA

\begin{tabular}{lll}
\hline Industry & $\%$ contribution to the total GDP of country & $\%$ contribution to the total export income of country \\
\hline Crude oil & $6-70^{\mathrm{a}}$ & $10-100$ \\
Refineries & $0.2-4.2^{\mathrm{b}}$ & $0.1-70$ \\
Fertilizers & $0.1-3^{\mathrm{c}}$ & $0-12$ \\
Potash & $0-3^{\mathrm{d}}$ & $0-9$ \\
Pig iron & $0.2^{\mathrm{e}}$ & 0.05
\end{tabular}

a Sources: Central Bank of the Islamic Republic of Iran-National Accounts (2012/2013) [total GDP of Iran for the year 2013 was obtained from World Bank Database (2005-2013)], Saudi Industrial Development Fund. Marketing Consultancy Division. Export Consultancy Unit (ECU) (2012), The Logistics Sector on the Southern Shores of the Western Mediterranean (2010), Central Statistical Organization-Iraq (2007), Eid et al. (2014), Rao (2010) [total GDP of Kuwait for the year 2005 was obtained from World Bank Database (2005-2013)], Istaitieh et al. (2007), According to M, Taib (personal communication, 4 February, 2015), Oman. Energy, Laws and Regulations Handbook (2015), Taib (2012)

b Sources: General Authority for Statistics, Kingdom of Saudi Arabia (2011), Eid et al. (2014), Bureau of Statistics and Census Libya (2010) [total GDP of Libya for the year 2009 was obtained from World Bank Database (2005-2013)], Central Bank of the Islamic Republic of IranNational Accounts (2012/2013), Encyclopedia Britannica Almanac (2010) (GDP per capita for Iraq (year 1995) was taken from UN data A World of Information (1995), population of Iraq in 1995 was taken from World bank data on total population), GCC Gulf Petrochemicals \& Chemicals Association (2012); GDP of refined products for Morocco was taken from UN data A world of information (2010) 2010 [total GDP of Morocco for the year 2010 was obtained from World Bank Database (2005-2013)]

c Sources: UN data A World of Information (2007-2010) [total GDP of Lebanon, Morocco, Iran for the years (2007-2010) was obtained from World Bank Database (2005-2013)], Mobbs (2005b)

d Sources: The Report: Emerging Jordan (2007)

e Sources: UN data A World of Information (2008), 2008 [total GDP of Algeria for the year 2008 was obtained from the World Bank Database (2005-2013)]

${ }^{f}$ Sources: value of commodity exports taken from UN Comtrade database (2009-2015), while total export income obtained from OPEC Annual Statistical Bulletin (2013) and World Bank Database (2009-2015) 
Table 2 Percentage shares of the GDP, total export income, relative water use to other industries, and relative pollution to textile industry for five major industries in relevant countries in the MENA region

\begin{tabular}{|c|c|c|c|c|c|c|c|}
\hline Country & Industry & $\begin{array}{l}\% \text { share of the total } \\
\text { country's GDP }\end{array}$ & Year & $\begin{array}{l}\% \text { share of the total } \\
\text { export income }\end{array}$ & Year & $\begin{array}{l}\text { Water use relative to } \\
\text { other industries }\end{array}$ & $\begin{array}{l}\text { Pollution relative to the } \\
\text { textile industry }\end{array}$ \\
\hline Egypt & Crude oil & $7.3^{\mathrm{a}}$ & $\begin{array}{l}2011 / \\
2012\end{array}$ & 10.3 & 2012 & $0.3^{\mathrm{g}}$ & 0.2 \\
\hline Iran & Refining & $4.0^{\mathrm{b}}$ & $\begin{array}{r}2012 / \\
2013\end{array}$ & 0.8 & 2011 & $0.6^{\mathrm{h}}$ & 1.3 \\
\hline Morocco & Fertilizers & $1.1^{\mathrm{c}}$ & 2007 & 11.3 & 2012 & $45.9^{\mathrm{i}}$ & 0.8 \\
\hline Jordan & Potash & $2.4^{\mathrm{d}}$ & 2007 & 8.5 & 2012 & $4.1^{\mathrm{j}}$ & 0.1 \\
\hline Algeria & Pig iron & $0.2^{\mathrm{e}}$ & 2008 & 0.05 & 2012 & $1.6^{\mathrm{i}}$ & - \\
\hline
\end{tabular}

${ }^{a}$ Eid et al. (2014)

${ }^{b}$ Central Bank of the Islamic Republic of Iran-National Accounts (2012/2013) [total GDP of Iran for the year 2013 was obtained from World Bank Database (2005-2013)]

${ }^{c}$ UN data A World of Information (2007-2010) [total GDP of Morocco was obtained from the World Bank Database (2005-2013)]

d The Report: Emerging Jordan (2007)

e UN data A World of Information (2008) [total GDP of Algeria was obtained from the World Bank Database (2005-2013)]

${ }^{\mathrm{f}}$ UN Comtrade database [total export income obtained from OPEC Annual Statistical Bulletin 2013 and World Bank Database (2009-2015)]

$\mathrm{g}$ This study, industrial water use is divided by that of the spinning and weaving obtained from Doss and Milne (2001), because the textile industry in Egypt is considered to be one of the most important industries, since it has a share of 3\% of GDP (27\% of total industrial production) (Ahmed 2009)

h This study, industrial water use is divided by that of sugar industry obtained from Ahmadi et al. (2004), since the latter industry is one of the largest water users in Iran (Ahmadi et al. 2004)

${ }^{\mathrm{i}}$ This study, industrial water use is divided by that of textile industry obtained from Pollution Prevention in the Textile Industry within the Mediterranean region (PPTIMR) (2002), since it contributes 17\% of the total industrial GDP and 10\% of GDP, which employs $42 \%$ of the total working force in Morocco (PPTIMR 2002, COFACE for safer trade 2015), and is a main industry in Algeria (SMEToolkit 2013)

$\mathrm{j}$ This study, industrial water use is divided by that in the manufacture of soft drinks and the production of mineral water (obtained from Karablieh 2012), since the latter industry is a major water user in Jordan (Karablieh 2012)

$\mathrm{k}$ This study, industrial pollution in terms of BOD is divided by the BOD emissions from the textile industry obtained from EconStats (19972006), since the textile industry contributes $7-45 \%$ of the total industrial BOD emission in these countries (EconStats 1997-2006)

Morocco and Tunisia provides employment for more than 3 million people, which is approximately $19.5 \%$ of the total labor force, and it generates earnings of approximately half a billion US \$ from the export of Tunisian olive oil (1.26\% of GDP) and 124 million US \$ from the export of Moroccan table olives and olive oil ( $0.14 \%$ of GDP) (International Olive Council (IOC) (2006a, b). The olive oil industries in Algeria, Egypt, Israel, Lebanon, Palestinian Territories, and Syria were selected because of environmental reasons, that is because olive oil mill effluent is among the strongest industrial wastewaters (e.g., chemical oxygen demand (COD): $6.4-162 \mathrm{~g} / \mathrm{l}$; BOD: $1.5-100 \mathrm{~g} / \mathrm{l}$; and phenols: $4.5 \mathrm{~g} / \mathrm{l}$ ), and it is harmful to the environment.

Data used in this study were collected from numerous sources which can be found in the supplementary material.

\section{Methodology and assumptions}

In the following section, we summarize the methods of calculating the yearly volumes of water use, wastewater generation, VW export, WWGE, BOD load for production/export, and GWF. More details can be found in the supplementary material. Note that for the specific volumes of water usage and wastewater generated by the production of the relevant items, the numbers (or rates) of the MENA industries were used.

\section{Calculation of water usage and wastewater generation related to production}

\section{Crude oil}

1. Water usage because of crude oil production = water for repressurizing oil fields (WRO) + water for washing the crude oil $(\mathrm{CW})$.

2. Wastewater generated because of crude oil production $=$ annual wastewater from desalter $=\mathrm{CW}+$ entrained formation water (EFW) wastewater.

\section{Refineries}

Data were obtained for the water requirements and wastewater generated in certain MENA refineries. 
Estimations were performed when the latter values were missing.

\section{Fertilizers}

1. The annual water requirement (AWR) for MENA fertilizer plants (except in Egypt, Algeria, Iran, and Syria) that produce ammonia was estimated as follows:

AWR $=$ annual cooling tower make-up water $($ ACTMW $)+$ part of the estimated boiler make-up water (PEBMW);

PEBMW < specific boiler make-up water $($ SBMW) $\times$ yearly production of ammonia and urea;

SBMW is in $\mathrm{m}^{3} /$ ton (ammonia and urea).

2. For MENA countries (except Egypt) that produce ammonia, the annual wastewater generated (AWG) is calculated as follows:

AWG $=$ ammonia cooling tower blowdown (ACTB).

Pig iron

1. The AWR related to the production of pig iron in Algeria $=$ specific water use because of the production of pig iron (SWUPI) $\times$ yearly production of pig iron.

SWUPI is an Algerian number in $\mathrm{m}^{3} /$ ton pig iron.

2. The AWG because of the production of pig iron in Algeria is stored, processed, and recycled (Organisation Mondiale de la Santé 1983).

\section{Olive oil}

Israel:

1. $\quad$ AWR $=$ specific water use for three-phase extraction systems (SWUTPES) $\times$ (annual olives produced - annual table olives produced).

SWUTPES is applied for a typical olive oil mill (OOM) in $\mathrm{m}^{3} /$ ton olives fed.

2. The AWG for the OOMs in Israel is obtained from Laor et al. (2007).

\section{Potash}

For Israel and Jordan:

1. $\mathrm{AWR}=$ specific average Jordanian water use (SAJWU) $\times$ yearly production of potash.

SAJWU is in $\mathrm{m}^{3} /$ ton potash.
2. The AWG is assumed to be equal to the AWR in the relevant countries.

\section{Calculation of net VW export}

The calculation of net VW exported from MENA to EU28 (VWE1-VWE2) (VWE is an abbreviation for the Virtual Water Exported) for two commodities is mentioned. VWE1 is estimated using a method that is analogous to the method used by Hoekstra and Hung (2002) and is presented as follows. The VWE2 is also estimated in the following section.

\section{Crude oil case}

The specific water demand (SWD) in $\mathrm{m}^{3} /$ ton crude was calculated as the sum of the $\mathrm{CW}$ and WRO in $\mathrm{m}^{3} /$ year divided by the annual production of crude oil (APCO) in tons:

$\mathrm{SWD}=(\mathrm{CW}+\mathrm{WRO}) / \mathrm{APCO}$

The VWE1 in $\mathrm{m}^{3} /$ year was estimated as follows:

VWE1 $=$ SWD $\times$ annual crude oil exported (ACOE) to EU28 (ACOE is an abbreviation for the Annual Crude Oil Exported).

The ACOE was obtained from the UN Comtrade database, which has the commodity code 2709 (HS1996).

VWE2 is the VW export in the form of crude oil from the EU28 to MENA and is estimated as follows:

VWE2 $=$ SWD $\times$ annual crude oil exported to MENA Net VW export $=$ VWE1 - VWE2.

\section{Phosphatic fertilizer (triple superphosphate) case}

Triple superphosphate The SWD is presented in $\mathrm{m}^{3} /$ ton triple superphosphate (TSP) and was calculated as the sum of the water required for TSP production (WTSP), sulfuric acid production (WSA), phosphoric acid production (WPA), and rock phosphate production (WRP) in $\mathrm{m}^{3} / y e a r$ divided by the annual production of TSP (APTSP) in tons:

$\mathrm{SWD}=(\mathrm{WTSP}+\mathrm{WSA}+\mathrm{WPA}+\mathrm{WRP}) / \mathrm{APTSP}$

VW export from MENA to EU28 (VWE1) was estimated as follows:

VWE1 $=$ SWD $\times$ annual TSP exported to EU28 (ATSPE)

VW export from EU28 to MENA in form of TSP (VWE2) is as follows:

VWE2 $=$ SWD $_{\mathrm{PA}} \times \mathrm{PARM}+\mathrm{SWD}_{\mathrm{SA}} \times-$

$\mathrm{SARM}+\mathrm{SWD}_{\mathrm{TSP}} \times \mathrm{TSP}$ exported

where

$\mathrm{SWD}_{\mathrm{PA}}$ is the specific water demand for the production of phosphoric acid in $\mathrm{m}^{3} /$ ton PA. 
PARM is the phosphoric acid amount required for the production of TSP in tons.

$\mathrm{SWD}_{\mathrm{SA}}$ is the specific water demand for the production of sulfuric acid in $\mathrm{m}^{3} /$ ton $\mathrm{SA}$.

SARM is the sulfuric acid amount required for the production of TSP in tons.

$\mathrm{SWD}_{\mathrm{TSP}}$ is the specific water demand for the production of TSP in $\mathrm{m}^{3} /$ ton TSP.

$\mathrm{TSP}_{\text {exported }}$ is the annual TSP exported to MENA in tons.

\section{Calculation of WWGE}

The calculation of wastewater generated because of exports from MENA to EU28 for one commodity is provided.

\section{Crude oil case}

The specific wastewater generation (SWG) was estimated in $\mathrm{m}^{3} /$ ton of crude oil as the sum of the CW and EFW in $\mathrm{m}^{3} /$ year, which was divided by APCO in tons:

$$
\begin{aligned}
& \mathrm{SWG}=(\mathrm{CW}+\mathrm{EFW}) / \mathrm{APCO} \\
& \mathrm{WWGE}=\mathrm{SWG} \times \mathrm{ACOE}
\end{aligned}
$$

\section{Calculation of GWF}

The GWF was calculated here by dividing the pollutant load by the difference between the ambient water quality standard for the pollutant (maximum acceptable concentration $\mathrm{C}_{\max }$ in mass/volume) and its natural concentration in the receiving water body $\left(\mathrm{C}_{\text {nat }}\right.$ in mass/volume).

The BOD load from production or export in the MENA region that is used in the calculation of GWF because of production or export was estimated as follows:

BOD load from crude oil production or export:

$\mathrm{BOD}_{\text {load }}=$ annual estimated volume of wastewater generated from crude oil production or export in MENA $\times$ typical BOD value for crude oil wastewater

The typical BOD value for crude oil wastewater was obtained from Wang et al. (2004).

\section{Results and interpretations}

\section{Water usage and wastewater generated because of production}

The total annual estimated volumes of water required for the six industries in the MENA region are summarized in Table 3 for the year 2011. Saudi Arabia has the highest requirement because of the crude oil and refining industry sector. For the export industries, the volume is approximately $4.26 \times 10^{9} \mathrm{~m}^{3}$, which can be calculated from the last row in Table 3. As an illustration, the total annual water withdrawal in the MENA region for agricultural and domestic purposes is $2.60 \times 10^{11}$ and $2.69 \times 10^{10} \mathrm{~m}^{3}$, respectively (FAO AQUASTAT (20002014), the data on which the total annual withdrawal is based are for different years ranging from 2000 to 2006). The crude oil and refining industry sector represents $77.5 \%$ of the total water required, and is followed by the fertilizer sector, which represents $21.7 \%$. Figure 1 shows the annual wastewater volumes (year 2011) of the five relevant export industries that range between $0 \times 10^{6}$ and $540 \times 10^{6} \mathrm{~m}^{3}$. Note that the pig iron industry does not produce effluent and the fertilizer industry has the highest volume.

\section{Net VW export and WWGE}

\section{Net VW for all industries (year 2015)}

The indirect pressure that EU28 imposes on the water resources of MENA countries and the region as a whole is summarized in Table 4. Iraq and Saudi Arabia are the largest net VW exporters because of the export of crude oil and refined petroleum products. The net VW export from the studied industries of the MENA region ranges from 0 to $1.3 \times 10^{8} \mathrm{~m}^{3}$, and it is approximately $3.0 \times 10^{8} \mathrm{~m}^{3}$ for the 20 countries, which is a sufficient volume to satisfy the water demands of approximately 5.5 million people (total MENA population in 2015 was 423.6 million people, world bank data on total population for the year 2015). The export of crude oil represents approximately $2.59 \times 10^{8} \mathrm{~m}^{3}$ of the industrial net VW export from this region, followed by the export of phosphatic/nitrogenous/ mixed fertilizers, which is approximately $6.5 \times 10^{7} \mathrm{~m}^{3}$. The greatest impact is observed on the Saudi Arabian hydrological system, where the net VW export represents approximately $1.6 \%$ of the actual renewable water resources and desalination capacity. The influence in Kuwait and Libya is noticeable (1.0\% for both countries), but in the other countries, it is much smaller. However, the overall water demand by industry in Kuwait, the UAE, Saudi Arabia, Oman, Qatar, Bahrain, and Libya contributes from 3 to $25 \%$ of the total actual renewable water resources and desalination capacity, which emphasizes the pressure of the industrial sector on the local water supply.

\section{WWGE (year 2015)}

The estimated WWGE volumes are shown in Fig. 2, which indicates that the fertilizer industry has the highest and the potash industry the lowest. For the fertilizer industry in Morocco and Tunisia, the WWGE represents $86.0 \%$ of the total volume for the fertilizer industry in all relevant MENA countries. 
Table 3 Water usage because of production by the six exporting industries in $10^{5} \mathrm{~m}^{3} /$ year

\begin{tabular}{|c|c|c|c|c|c|c|}
\hline \multirow[t]{2}{*}{ Country } & \multicolumn{6}{|l|}{ Industry } \\
\hline & $\begin{array}{l}\text { Crude oil (year } \\
\text { 2011) }\end{array}$ & $\begin{array}{l}\text { Refineries (year } \\
\text { 2011) }\end{array}$ & $\begin{array}{l}\text { Fertilizers (year } \\
\text { 2011) }\end{array}$ & $\begin{array}{l}\text { Potash (year } \\
\text { 2011) }\end{array}$ & $\begin{array}{l}\text { Pig iron (year } \\
\text { 2011) }\end{array}$ & $\begin{array}{l}\text { Olive oil (year } \\
\text { 2011) }\end{array}$ \\
\hline Algeria & 847.0 & 279.3 & 59.02 & - & 90.0 & 0.6 \\
\hline Bahrain & - & 157.4 & - & - & - & - \\
\hline Djibouti & - & - & - & - & - & - \\
\hline Egypt & 376.4 & 447.0 & 1442.9 & - & - & 1.9 \\
\hline Iran & 2478.1 & 851.6 & 640.3 & - & - & - \\
\hline Iraq & 2381.5 & 395.7 & - & - & - & - \\
\hline Israel & - & 136.6 & 270.5 & 142.5 & - & 0.5 \\
\hline Jordan & - & - & - & 99.7 & - & - \\
\hline Kuwait & 1733.6 & 581.0 & 145.0 & - & - & - \\
\hline Lebanon & - & - & 23.5 & - & - & 0.3 \\
\hline Libya & 220.7 & 235.0 & 14.6 & - & - & - \\
\hline Morocco & - & 96.1 & 4634.6 & - & - & 3.1 \\
\hline Oman & 605.2 & 43.8 & - & - & - & - \\
\hline $\begin{array}{l}\text { Palestinian } \\
\text { territories }\end{array}$ & - & - & - & - & - & 0.2 \\
\hline Qatar & 542.3 & 113.1 & - & - & - & - \\
\hline Saudi Arabia & $16,389.0$ & 1810.7 & 1202.5 & - & - & - \\
\hline Syria & - & - & 186.0 & - & - & 3.8 \\
\hline Tunisia & 43.7 & 2.5 & 544.1 & - & - & 1.9 \\
\hline UAE & 1718.5 & 480.0 & 87.4 & - & - & - \\
\hline Yemen & - & - & - & - & - & - \\
\hline Total & $27,335.8$ & 5629.3 & 9250.0 & 242.2 & 90.0 & 12.0 \\
\hline
\end{tabular}

- This industry is either not present in the relevant country or is present and does not export to EU28

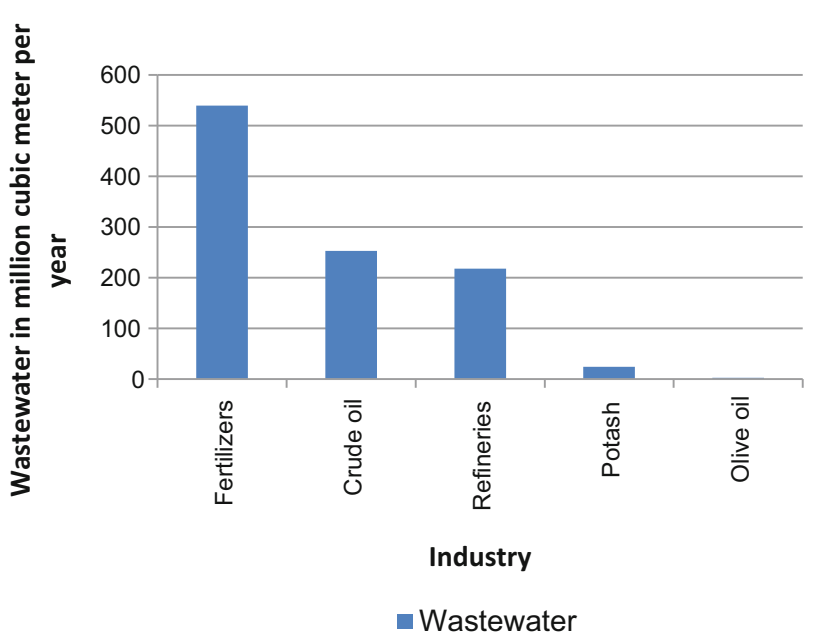

Fig. 1 Annual wastewater volumes generated from the five exporting industries within the MENA region in 2011

\section{GWF}

Figure 3 shows the GWFs of the studied MENA industries (GWF for production and export are for the years 2011 and 2015, respectively). The GWF related to production is highest for crude oil and lowest for potash (the GWF of the pig iron industry is zero, because this industry does not produce effluent). The GWF related to production for the six industries is $111.8 \times 10^{9} \mathrm{~m}^{3} /$ year. As a comparison, the Nile annual average river discharge measured at six stations is $55.49 \times 10^{9} \mathrm{~m}^{3} /$ year (Center for Sustainability and the Global Environment Gaylord Nelson Institute for Environmental Studies, University of Wisconsin-Madison, Global River Discharge Database 1976-1987). Average annual value is based on the time period 1976-1987). If it is assumed that these five industries discharge their effluents into the Nile River, the pollution assimilation capacity of the latter would be consumed. Furthermore, the BOD concentration of the Nile would not remain below the ambient BOD water quality standard of that basin.

\section{Discussion}

\section{Water and VW}

This study focuses on estimating the water requirements and wastewater generation of six relevant export industries 
Table 4 Water and net VW statistics for MENA countries

\begin{tabular}{|c|c|c|c|c|c|c|}
\hline Country & $\begin{array}{l}\text { Net VW } \\
\text { exported } \\
\left(10^{6} \mathrm{~m}^{3} / \text { year) }\right. \\
\text { (year 2015) }\end{array}$ & $\begin{array}{l}\text { Net VW } \\
\text { export/ } \\
\text { water } \\
\text { used }(\%)\end{array}$ & $\begin{array}{l}\text { Total actual } \\
\text { renewable water } \\
\text { resources }\left(10^{9} \mathrm{~m}^{3} /\right. \\
\text { year) }^{\mathrm{a}} \text { (year 2014) }\end{array}$ & $\begin{array}{l}\text { Desalination } \\
\text { capacity } \\
\left(10^{6} \mathrm{~m}^{3} / \text { year }\right)^{\mathrm{b}} \\
\text { (year 2015) }\end{array}$ & $\begin{array}{l}\text { Net VW export/(total } \\
\text { actual renewable } \\
\text { water + desalination } \\
\text { capacity) }(\%)\end{array}$ & $\begin{array}{l}\text { Water used for industry/ } \\
\text { (total actual renewable } \\
\text { water }+ \text { desalination } \\
\text { capacity) }(\%)\end{array}$ \\
\hline Algeria & 41.8 & 32.7 & 11.7 & 1034.7 & 0.3 & 1.0 \\
\hline Bahrain & 0.0 & - & 0.1 & 399.3 & - & 3.1 \\
\hline Djibouti & 0.0 & - & 0.3 & - & - & 0.0 \\
\hline Egypt & -3.4 & - & 58.3 & 525.4 & - & 0.4 \\
\hline Iran & -18.4 & - & 137.0 & 375.2 & - & 0.3 \\
\hline Iraq & 75.0 & 27.0 & 89.9 & 337.9 & 0.1 & 0.3 \\
\hline Israel & 7.0 & 12.8 & 1.8 & 821.1 & 0.3 & 2.1 \\
\hline Jordan & -1.8 & - & 0.9 & 97.7 & - & 1.0 \\
\hline Kuwait & 13.9 & 5.7 & 0.0 & 1365.7 & 1.0 & 17.8 \\
\hline Lebanon & -10.3 & - & 4.5 & 8.8 & - & 0.1 \\
\hline Libya & 10.9 & 23.2 & 0.7 & 439.5 & 1.0 & 4.1 \\
\hline Morocco & 52.9 & 11.2 & 29.0 & 135.3 & 0.2 & 1.6 \\
\hline Oman & -1.5 & - & 1.4 & 653.6 & - & 3.2 \\
\hline $\begin{array}{l}\text { Palestinian } \\
\text { Territories }\end{array}$ & 0.0 & - & 0.8 & 10.6 & - & 0.0 \\
\hline Qatar & 1.7 & 2.7 & 0.1 & 741.9 & 0.2 & 8.2 \\
\hline $\begin{array}{l}\text { Saudi } \\
\text { Arabia }\end{array}$ & 125.2 & 6.5 & 2.4 & 5437.8 & 1.6 & 24.8 \\
\hline Syria & 1.4 & 7.4 & 16.8 & 0.0 & 0.0 & 0.1 \\
\hline Tunisia & 9.7 & 16.4 & 4.6 & 91.3 & 0.2 & 1.3 \\
\hline UAE & -3.4 & - & 0.2 & 3429.1 & - & 6.4 \\
\hline Yemen & -0.8 & - & 2.1 & 26.0 & - & 0.0 \\
\hline Total & 300.0 & 7.0 & 362.5 & $15,930.9$ & 0.1 & 1.1 \\
\hline
\end{tabular}

a Source: FAO AQUASTAT

b Source: GWI-Desaldata (desalination capacities for Lebanon and Syria are for the year 2013)

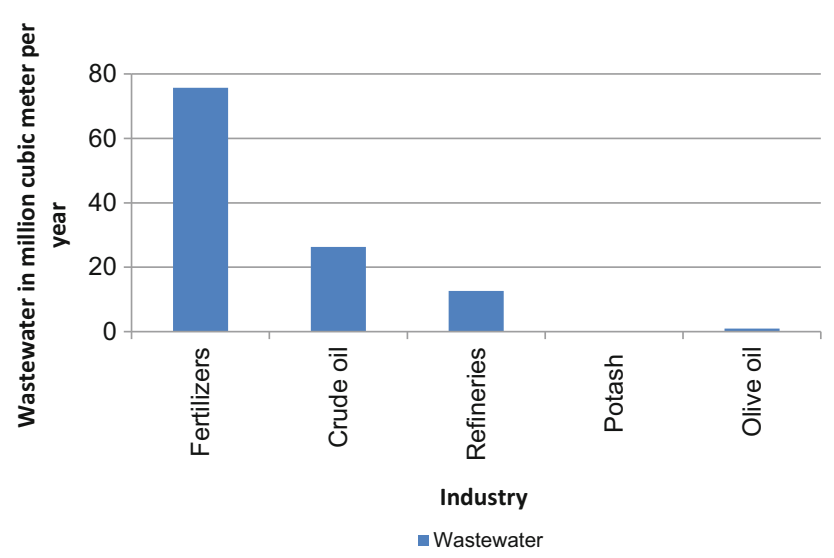

Fig. 2 WWGE for the five exporting industries of the MENA region for the year 2015

in some countries of the MENA region. The goal is to select and analyze important industries that export goods to EU28 (the classification of export and non-export

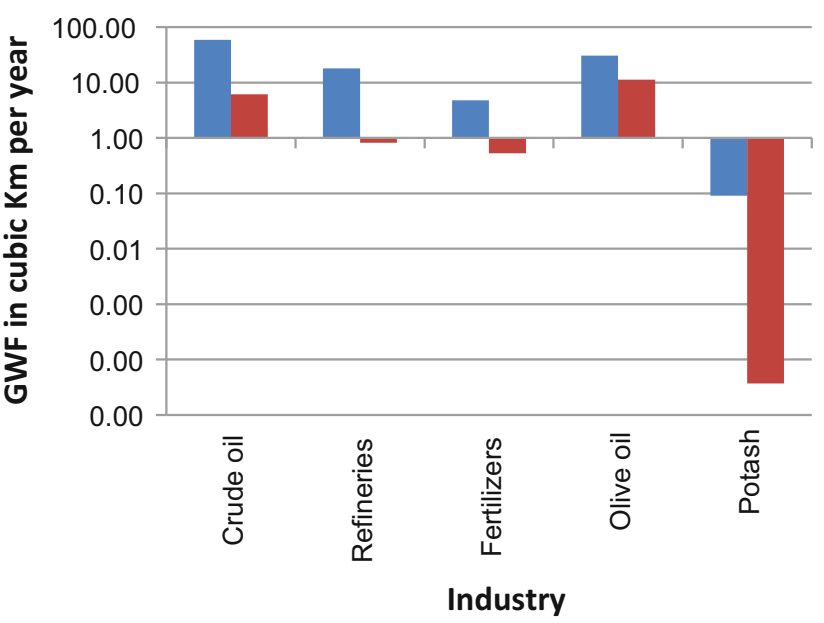

- Grey water footrpint caused by production - Grey water footprint caused by export

Fig. 3 Grey water footprints for MENA industries because of production and export. GWF for production and export is for the years 2011 and 2015, respectively 


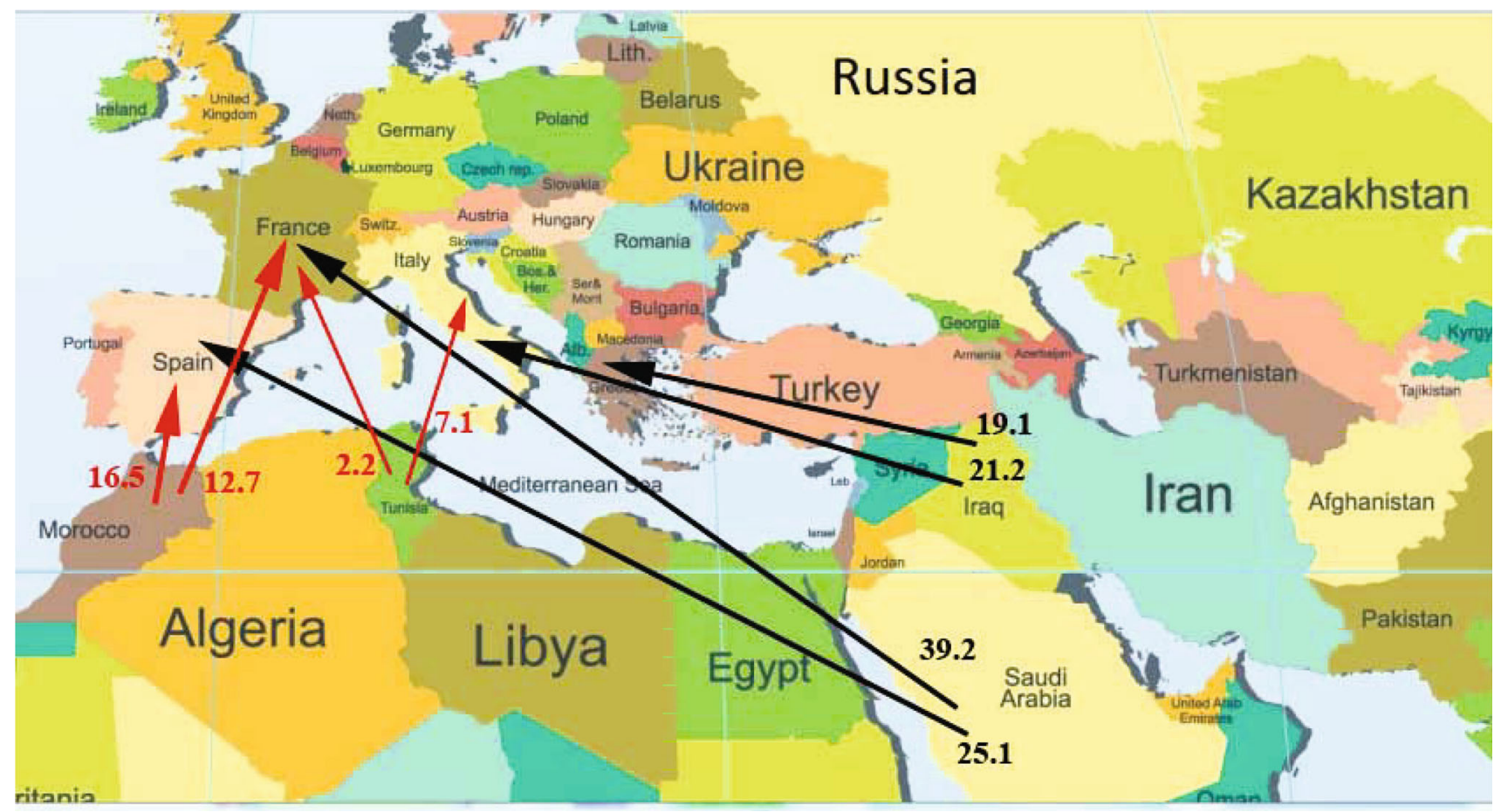

Fig. 4 Net VW export from four MENA exporting countries to four EU28 countries in terms of crude oil (black) and diammonium phosphate mixed fertilizer $(r e d)$. The numbers represent millions of cubic meter of net VW exported in 2015 (map reference: Alhadeff 2015)

industries has been based on the UN Comtrade database for the year 2015) and quantify/evaluate the indirect pressure that EU28 poses on the MENA hydrological system.

The export industry that is most relevant in terms of water demand within MENA is that of crude oil. As previously shown, the estimated water usage for this industry is approximately $2.73 \times 10^{9} \mathrm{~m}^{3}$. The water required to repressurize oil fields is the primary use for this industry. For example, it is common practice in large parts of North Africa to use freshwater from the regionally extensive Cretaceous aquifer as injection water for oil reservoir pressure maintenance (Hardisty 2010), whereas Libya repressurizes its oil fields using freshwater from Nubian sandstone and analogous aquifers, and it is estimated that this withdrawal exceeds $75 \times 10^{6} \mathrm{~m}^{3}$ (Hardisty 2010). Moreover, countries in the Middle East also use water for pressure maintenance. For example, the largest oil field in Saudi Arabia (Al-Ghawar) uses approximately $4.06 \times 10^{8} \mathrm{~m}^{3}$ of treated sea water annually for pressure maintenance (Durham 2005). Therefore, in Libya and Saudi Arabia, more than $4.81 \times 10^{8} \mathrm{~m}^{3}$ of water is used annually for injection purposes. In addition, the Al Furat Petroleum Company of Syria uses water from the Euphrates River as well as oilfield produced water to maintain the pressure of these fields controlled by this company (Al Furat Petroleum Company Website 2006).

Regarding VW, the indirect water use by EU28 is primarily caused by the import of crude oil, refined petroleum products, and fertilizer goods, which amounts to $99.82 \%$ of the total indirect water use attributed to EU28 countries through the import of the six studied commodities. This finding is based on estimations calculated from many statistical data sources (e.g., UN Comtrade, Fertilizer Statistical Yearbook 2011 of the Arab Fertilizer Association, US Energy Information Administration). In this regard, Fig. 4 shows the net VW flows from four MENA countries to four EU28 countries for the year 2015. Iraq and Saudi Arabia are the largest net VW exporters in terms of crude oil, whereas Morocco/Tunisia are the largest net VW exporters in terms of diammonium phosphate.

\section{Pollution}

The threat of pollution imposed on the environment by the six relevant industries is also considered. Therefore, the GWF pollution related to production and export, the pollution characteristics, certain liquid emission effects, and the emissions mitigation practices in certain MENA countries is highlighted and discussed in this section. With regard to pollution caused by production, the highest polluter is the crude oil industry, and is followed by olive oil industry. The ratio of $\mathrm{GWF}_{\text {export }}$ to $\mathrm{GWF}_{\text {production }}$ ranges between 0 and $37 \%$, with the olive oil industry having the highest percentage $(36.75 \%)$ and potash having the lowest $(0.04 \%)$. The pollution of water bodies caused by production is relevant for crude oil, refined petroleum, olive 
oil, and fertilizers, although it could be considered negligible for potash (see Fig. 3). The pollution caused by exports is relevant for the crude oil and olive oil industries, because their annual combined GWFs represent $92.8 \%$ of the total from the export of all goods $\left(\mathrm{GWF}_{\text {export }} /\right.$ $\mathrm{GWF}_{\text {production }}$ were calculated based on information from numerous sources which can be found in the supplementary material).

The liquid emissions of crude oil, refined petroleum, and olive oil industries have been selected for the purpose of investigating the pollution. The value of the production GWF in Fig. 3 has been used as the criterion for the selection: the latter emissions display the largest three values in Fig. 3. The liquid effluents from the crude oil, refined petroleum, and olive mill industries have their own characteristics. The effluent from crude oil production contains a complex mixture of inorganic compounds (silt, salts, scale salts, Naturally Occurring Radioactive Materials, and metals) and organic compounds (heavy or light crude oils, and acid gases) (AlAnezi et al. 2012); the effluent from refineries contains high concentrations of toxic derivatives (oil and grease, phenols, sulfides, cyanides, suspended solids, and nitrogen compounds, as well as heavy metals such as iron, copper, selenium, zinc, molybdenum, etc.) (Nwanyanwu and Abu 2010); and the acidic dark-colored effluent from olive oil mills contains phytotoxic and biotoxic substances (Niaounakis and Halvadakis 2006).

The produced water from crude oil production contains BOD values ranging from 50 to $1400 \mathrm{ppm}$, in which oil and grease are the main pollutants of concern (Wang et al. 2004). The continuous discharge of formation water into a freshwater environment could cause major damage to aquatic and agricultural resources (Obire and Amusan 2003). This is probably the case for oilfield production sites in MENA. For example, the Saudi Arabian Oil Company (ARAMCO) deals with the formation water from crude oil production along with the gas and oil. The three streams are sent to a separation plant where the formation water is separated from the other two streams and afterwards directed to a treatment plant (The Oil Drum 2009), although there is no information on the method of treatment. Another example is the practices in dealing with the formation water in Kuwait. The produced water from the oil fields in North Kuwait was disposed in lined or unlined pits. It is not mentioned whether this water was treated or not. The groundwater in Kuwait was found to be contaminated due to these practices (Al-Rashed et al. 2010). A final example is that of Oman which paid attention to the groundwater pollution due to the disposal of produced water in the shallow water bearing strata in the past. The latter country has prohibited this practice and all the formation water disposals are being switched to deeper bearing strata (Hirayama et al. 2002).

Refineries generate polluted wastewater that contains BOD levels of approximately 150-250 ppm (Pollution Prevention and Abatement Handbook, World Bank Group 1998). The ineffectiveness of refinery wastewater treatment causes these effluents to become dangerous and leads to the accumulation of toxic compounds in the receiving water bodies, which has potentially serious consequences for the ecosystem (Nwanyanwu and Abu 2010). This is most likely the case for the refineries in the MENA region. For example, wastewater from the Homs Refinery in Syria is subject to only simple physical treatment (separation of floating oil) before its discharge into the Orontes River (The Arabic Network for Human Rights Information 2007), and the wastewater from each of the three refineries in Kuwait is discharged into the Arabian Gulf (Kuwait National Petroleum Company (KNPC) Annual report 2006-2007), and although this water is treated, there is no information on the method of treatment. Oil and grease are the most critical parameters observed in Kuwait's refinery liquid emissions (KNPC Annual report 2006-2007). The application of oil-refinery effluent over a prolonged period on certain types of soil has been reported to cause an increase in the soil's heavy metal content $(\mathrm{Zn}, \mathrm{Fe}, \mathrm{Cu}, \mathrm{Mn}$, $\mathrm{Cr}, \mathrm{Pb}$, and $\mathrm{Ni}$ ), with levels potentially accumulating to toxic levels, which could make the soil become phytotoxic (Rajesh et al. 2009). Such changes should be a cause for concern in countries that use refinery wastewater for irrigation, such as in Jordan (Mohsen and Jaber 2002).

The high BOD value of olive mill wastewater causes it to have high organic loads, and it is classified as among the strongest industrial effluents (Niaounakis and Halvadakis 2006). The pollution load of olive mill effluent has been reported to be 5-10 or even 25-80 times larger than that of domestic sewage (Boari et al. 1984; Schmidt and Knobloch 2000). In Morocco, most of the latter wastewater is discharged directly or through the public sewage system in its raw form without any treatment. These actions pose serious environmental problems. In Lebanon, it is also discharged in raw form to water bodies ( $7 \%$ of the total), applied to land (30\% of the total), and discharged to the sewage system (27\% of the total) (Hamdan 2009). Values for the non-biodegradable COD for olive oil mill wastewater using different biological treatment technologies have previously been reported by Yeşilada et al. (1999); Gonçalves et al. (2009); Ammary (2005); Hamdi et al. (1992). Yeşilada et al. used seven strains of fungi as treatment, and the lowest value was $4.46 \mathrm{~g} / \mathrm{l}$. However, Gonçalves et al. used six different yeasts as treatment, and the value ranged from 53.4 to $122.6 \mathrm{~g} / \mathrm{l}$. Hamdi et al. applied three biological treatment steps in series and obtained a value of $13.64 \mathrm{~g} / \mathrm{l}$, 
whereas Ammary used an anaerobic sequencing batch reactor to obtain $2.7 \mathrm{~g} / 1$.

\section{Policies to mitigate water scarcity in the MENA region}

By 2050, it is estimated that all countries in the MENA region (except Iraq) will be subject to water scarcity (Michel et al. 2012), and one of the primary causes is population growth. Despite using the media to encourage birth control, such as in Jordan, a $15.5 \%$ increase in Jordan's population occurred from 2010 to 2014 (World Bank Data on total population for the time period from 2010 to 2014). In addition, the remaining MENA countries also experienced an increasing trend in population in the same time period. For example, by 2050, it is expected that Iraq's population will more than double (2.6-fold) and Syria's population will increase by $50 \%$. In addition, migration related to the warfare occurring in Syria and Iraq has also increased the pressure on the limited water resources of certain MENA countries. Jordan is strongly influenced by this with 2 million immigrants from Syria and Iraq living in this country counting 6.98 million inhabitants (World bank data on total population 1995-2015) and substantially increasing the pressure on its limited water resources. To alleviate this pressure, it is suggested that Jordan follows a policy of acquiring as much aid as possible from international organizations and requesting that the immigrants return home as soon as the conditions in their countries improve.

Because the trend for the future is an increase in the population of the MENA region, the solution for managing its limited water resources is to implement integrated water resources management (IWRM) policies. The latter have been applied in Egypt, Jordan, and Yemen. In January 2005, Egypt issued a national water resources plan based on the IWRM concept, and this plan focused on conserving current water resources instead of finding new sources (i.e., bolstering supply). Jordan has successfully implemented the latter concept, and it has been using Islamic teachings since the early 1990s to increase the public awareness of water conservation within the context of IWRM (Michel et al. 2012). Yemen also attempted to incorporate the latter into its national water policy in the past decade and plans have included the involvement of farmers in water management and teaching IWRM in 2004 in Sana University (Michel et al. 2012). Because of the current political unrest, an IWRM would not help Yemen, because this requires a strong government and stable conditions.

Bolstering water supplies is a problem in the MENA region, because large projects, such as dam construction, river diversions, and sea water desalination, focus on the supply side of water management. The MENA water policies should be implemented to support methods/ projects that focus on water conservation, such as the use of drip irrigation for agriculture.

Encouraging bilateral IWRM-based agreements between MENA countries that share water resources helps to improve the stewardship of these resources through cooperation. An example of such an agreement is represented by the sharing of the Disi aquifer, which is a groundwater resource, between Jordan and Saudi Arabia. However, there is a dispute regarding this aquifer that has not been resolved, and there is a silent pumping race between these two countries in which each is attempting to obtain the greatest amount of water from the aquifer without cooperation (Allen 2010).

Despite water management strategies that are implemented in countries of the MENA region, they still need more water resources. This is why policies are currently followed to build several projects of sea water desalination. The latter are now in their phase of construction. In Jordan, for example, there is the Red Sea Desalination Project at Aqaba which will produce $80-100$ million $\mathrm{m}^{3}$ of desalinated sea water in its initial phase of commercial operation in 2018 (Jordan Valley Authority 2014). This desalinated water will be shared between Israel, Jordan, and Palestinian Authorities. Egypt will be constructing a desalination project consisting of five plants in the Egyptian governorate of South Sinai with a combined production capacity of $60,000 \mathrm{~m}^{3} /$ day (Construction Review Online 2016). Kuwait Fund for Arab Economic Development will support construction of this project by raising funds totaling up to 98.6 million US \$ in form of loan (Construction Review Online 2016). A final example is the Al Khafji Solar Saline Water Reverse Osmosis (Solar SWRO) Desalination Plant near the Kuwait border in Saudi Arabia, due to be completed in 2017, is set to be the world's largest facility of its kind. The plant will be capable of treating $30,000 \mathrm{~m}^{3}$ of water every day, which can supply over 100,000 people daily (Living water 2016).

Other policies of the MENA countries state that their industries should invest and implement the latest techniques and technologies to reduce the water use. For example, they could cooperate with General Electric (GE) in the United States that provided technology to reduce water consumption in a Canadian petroleum refinery (Hydrocarbon Processing 2016) and a Steel producer in Indiana USA (Hardcastle 2016). Regarding the Canadian Petroleum Refinery, GE provided an advanced water recycling technology, which consists of combining a membrane bioreactor and a high efficiency reverse osmosis system to recycle and reuse about $7600 \mathrm{~m}^{3}$ of wastewater a day. After commissioning, the Canadian refinery will reduce its freshwater use by 28\% (Hydrocarbon Processing 2016). Moreover, the US Steel producer used a rotary vacuum filter provided by GE to dewater sludge produced by this 
company, and the water produced has been reused as makeup to cooling systems (Hardcastle 2016). Another example is a Midwestern refinery in the US, which built an integrated membrane facility on its site for the treatment of multiple water sources (among which are refinery's wastewater and municipal wastewater) to be reused (Close 2016). The membrane facility consisted of microfiltration, nanofiltration, and reverse osmosis membranes. The Midwestern refinery was able to reduce water consumption by about 1.5 million gallons daily (Close 2016). A final example is the two-phase olive oil extraction, which uses less water than three-phase extraction systems (Azbar et al. 2004). This technology should be replaced by three-phase extraction systems currently in use in MENA countries such as Israel. The countries of the MENA region can learn from the Spanish experience where about $90 \%$ of olive oil mills use two-phase extraction systems (Spanish Ministry of Environment 2000).

Further methods of mitigating water scarcity problems in the MENA region include policies to encourage the contribution of the private sector in water management. The public sector in many of the latter countries suffers from poor management in the water sector, which could be resolved through cooperation between the private and public sectors to alleviate water scarcity. The MENA governments should implement policies (such as raising water tariffs) that will instill confidence in the private sector, so that their investments in the water sector will be returned within a reasonable time period (return on investment). It is worthwhile to mention that few countries in MENA have succeeded in achieving private sector contributions (Michel et al. 2012).

Finally, it should be mentioned that Islam, as the main religion of MENA countries, could help assist water conservation efforts to a great extent. Islamic law provides detailed information on the subject of water, and it is recognized as a social and political power in that region. Therefore, Muslim societies prefer to receive environmental education from their religious leaders as revealed by surveys (Wickström 2010). Imams could be educated on the water scarcity problem, and they could increase public awareness of water conservation during Friday prayers in mosques, which are among the most efficient locations for providing public education on all topics regarding daily life. However, the responsibility for educating the public on how to best manage water demand should not rest solely on the shoulders of mosques and religious schools; rather, it should be extended to the entire educational system. Islam says that water cannot be owned and it belongs to everyone. If this concept is practically realized, the disputes related to transboundary waters in this region would be resolved. An example of this type of dispute is between Turkey, Iraq, and Syria over the Tigris-Euphrates basin.
Turkey constructed an extensive dam and hydropower project on the Tigris and Euphrates rivers, thus reducing their flows to Iraq by $80 \%$ and to Syria by $40 \%$ (Kleyn 2012). The Turkish government has stated that it owns these water resources and has the right to manage them according to the water and economic needs of Turkey (Michel et al. 2012). There is also the transboundary water dispute between Egypt, Sudan, and Ethiopia due to the Grand Renaissance Dam that will affect the flow of the Nile River upstream. Although Egypt and Sudan had, and still have, strong opposition to this dam since the beginning of its construction in April 2011, the Ethiopians insist to complete the dam, resulting in diplomatic disputes between the three aforementioned countries. The completion of this dam would have catastrophic effects on Sudan and Egypt. The Egyptian experts claim that its construction would result in a loss of $60 \%$ of Egypt's agricultural land, and its share of water resources from the Nile would decrease by 9-12 billion $\mathrm{m}^{3}$ per year (Ezz Al Arab 2015). Naser Faruqui (a leading researcher in water management) suggested solutions to these complex disputes, which is to establish an Islamic council that has the power to judge and mediate resolutions to these disputes between the states that share transboundary waters.

\section{Climate change}

The emissions of greenhouse gases into the Earth's atmosphere caused its composition to change resulting in temperature rise (Zereini and Hötzl 2008). Projections show that global warming will be between 1 and $6.3{ }^{\circ} \mathrm{C}$ in 2100 (Mosbrugger 2008). Furthermore, predictions say that North Africa's annual average temperature rise due to climatic changes will be higher than the average expected for the planet (Radhouane 2013). North Africa would be particularly affected by droughts that would be more frequent, more intense, and longer-lasting. Several studies indicate (Evans 2010; Kundzewicz et al. 2007; Ragab and Prudhomme 2000) that the precipitation in the MENA region will decrease from 5 to $30 \%$. The predictions also announce a drop of 4-27\% in annual rainfall in North Africa (Radhouane 2013). Indeed, Middle Eastern countries experienced precipitation decrease. For example, the overall volume of precipitation in the Lebanese coastal zone has dropped from $914.5 \mathrm{~mm}$ in 1976-1977 to $718 \mathrm{~mm}$ in 1995-1996. Such a decrease is also seen in the amount of falling snow in the mountainous areas of Lebanon, where it sharply decreased from $499 \mathrm{~cm}$ in 1965-1966 to $380 \mathrm{~cm}$ in 1995-1996 (Arkadan 2008). Another phenomenon accompanied by climatic change is desertification. The latter is a form of land degradation by which land becomes more arid (Lane 2014). The main cause of desertification is the removal of plant life (United 
Nations Convention to Combat Desertification (UNCCD) 2014). Plant removal is caused by two dominant reasons; one of them is climatic change (UNCCD 2014), that results in temperature rise and precipitation decrease. This can cause drought conditions and prevents the sustained growth of vegetation (UNCCD 2014). The Mediterranean countries are already suffering from desertification and climatic changes would only exacerbate this phenomenon (Radhouane 2013).

\section{Water resources/reservoirs and their potentialities in the MENA region}

MENA has an actual renewable water resource per capita value of about $1100 \mathrm{~m}^{3} /$ year (World Bank 2007), which is far below the water security threshold of $1700 \mathrm{~m}^{3} /$ year. This region uses more water than it receives each year (World Bank 2007). Ragab and Prudhomme (2000) estimated that Tunisia is using $83 \%$ of these resources, and Egypt $92 \%$. Based on the average for 2000-2009, the potential of surface and ground water supply in MENA is 171 and $48 \mathrm{~km}^{3}$, respectively (World Bank 2012). This shows that there is more dependence on surface water for the daily human activities than ground water. Some countries depend on surface water as the main water resource (such as Egypt) others depend on groundwater (such as Jordan). Egypt's main freshwater resource is the Nile River and two groundwater aquifers (the first comprises groundwater in the Nile Valley and Delta, and a second aquifer which is non-renewable in the western desert) (Egypt National Action Program to Combat Desertification 2005). The estimated average annual discharge of the Nile River at Aswan is 84 billion $\mathrm{m}^{3}$, while the annual withdrawal from Nile and Delta aquifers is 6.13 billion $\mathrm{m}^{3}$ (Egypt National Action Program to Combat Desertification 2005). As for Jordan, the surface water is very limited, and therefore, the groundwater is the main water source (Al-Zyoud et al. 2015). Most of the groundwater aquifers in Jordan are overexploited (Jordan Ministry of Water and Irrigation (JMWI) 2013). There are 12 important aquifers in Jordan from which a combined abstraction of about 540 million $\mathrm{m}^{3}$ water has happened in the year 2013 (JMWI 2013). Nine out of the twelve important aquifers in Jordan are overexploited [safe yield of the 9 aquifers: 280.5 million $\mathrm{m}^{3}$ (JMWI 2013), total combined abstraction from these nine basins: 440.8 million $\mathrm{m}^{3}$ (JMWI 2013)].

\section{Conclusions}

The water demand and pollution potential of the exporting and non-exporting industries in the MENA region are considerable. The net VW export to EU28 caused by the net flow of export commodities to EU28 countries increases this pressure. The estimations of water usage and wastewater generation were obtained by applying Arabicspecific figures. The Saudi Arabian hydrological system is under the greatest pressure internally as well as externally (net export to EU28). The pollution from these industries is a cause for concern, especially because of the presumable discharge of their wastewater directly into the environment or through the public sewage system in raw form or with only partial treatment, which occurs for olive mill wastewater in Morocco and Lebanon. Indirect water usage by EU28 countries is most relevant for the crude oil, refined petroleum, and fertilizer industries. In terms of the GWF, water body pollution caused by production water is most relevant for the crude oil, refined petroleum, and olive oil industries. Although, water body pollution caused by the export of goods is also relevant for the crude oil industry and olive oil mills. The MENA industries do not have the technological development and water conservation techniques possessed by EU28 industries. Presumably, there are a number of factors that contribute to water loss in the exporting industries, and effective measures have not been provided to counteract such losses. However, the EU28 and MENA countries should cooperate to reduce industrial water requirements by supporting the implementation of the latest technologies to alleviate the environmental impacts of these industries. This suggestion must be implemented, because the scarcity of water resources in MENA continues to be a cause of concern due to (1) population growth [1.8\% in MENA for the year 2015 (World Bank3 2015)]; (2) a lack of precipitation, which reduces the actual renewable water resources per capita by several fold compared with those of water-rich countries; and (3) climate change.

Acknowledgements We would like to thank Prof. Elias Salameh at the University of Jordan for his valuable comments on this manuscript. We would also like to thank all of those who provided us with statistical data.

\section{Compliance with ethical standards}

Conflict of interest On behalf of all authors, the corresponding author states that there is no conflict of interest.

\section{References}

Abderrahman WA (2009) Water demand management in Saudi Arabia (Chapter 6). International Development Research Centre, Canada

Ahmadi M, Tajrishy M, Abrishamchi A (2004) GIS Assessment of food industrial location in iran for management of water resources. In: International Conference on Security and Sustainability in Water Resources, Kathmondu, Nepal 
Ahmed H (2009) Textile industry in Egypt. http://www.academia. edu/5705443/Textile_industry_in_Egypt. Accessed 7 Mar 2015

Al Furat Petroleum Company website (2006) http://www.afpc.sy/ Default_e.aspx. Accessed 7 Mar 2011

AlAnezi KM, Belkharchouche M, Alali S, Abuhaimed W (2012) Produced water characterization in Kuwait and its impact on environment. Desalin Water Treat 51(1):1-5

Alhadeff I (2015) The war for the oil of Libya. https://iakal. wordpress.com/2015/08/20/the-war-for-the-oil-of-libya/. Accessed 21 Jan 2017

Allan JA (1993) Fortunately there are substitutes for water otherwise our hydro-political futures would be impossible. In: Overseas Development Administration (ed) Priorities for water resources allocation and management. Overseas Development Administration, London, pp 13-26

Allen J (2010) Disi Aquifer-Jordan and Saudi Arabia, transboundary water resources. http://www.ce.utexas.edu/prof/mckinney/ce3 97/Topics/Groundwater/Groundwater_Disi\%282010\%29.pdf. Accessed 8 Jan 2015

Al-Rashed M, Mukhopadhyay A, Al-Senafy M, Ghoneim H, Abbas A (2010) Contamination of groundwater from oil field water disposal pits in Kuwait. Arab J Sci Eng 35(1B):105

Al-Zyoud S, Rühaak W, Forootan E, Sass I (2015) Over exploitation of groundwater in the Centre of Amman Zarqa Basin-Jordan: evaluation of well data and GRACE satellite observations. Resources 4:819-830

Ammary BY (2005) Treatment of olive mill wastewater using an anaerobic sequencing batch reactor. Desalination 177(1-3):157-165

Arkadan AM (2008) Climatic changes in lebanon, predicting uncertain precipitation events-do climatic cycles exist? In: Zereini F, Hötzl $\mathrm{H}$ (eds) Climatic changes and water resources in the Middle East and North Africa. Springer-Verlag, Berlin, pp 59-74

Azbar N et al (2004) A review of waste management options in olive oil production. Crit Rev Environ Sci Technol 34:209-247

Boari $G$ et al (1984) Anaerobic digestion of olive oil mill wastewaters. Agric Wastes 10(3):161-175

Bureau of statistics and census Libya (2010) http://bsc.ly/\#. Accessed 27 Jan 2015

Center for Sustainability and the Global Environment Gaylord Nelson Institute for Environmental Studies, University of WisconsinMadison (1976-1987) River discharge database. https://nelson. wisc.edu/sage/data-and-models/riverdata/. Accessed 27 Jul 2011

Central Bank of the Islamic Republic of Iran (2012/2013). http:// www.cbi.ir/simplelist/5796.aspx. Accessed 29 Jan 2015

Central Statistical Organization-Iraq (2007). http://cosit.gov.iq/en/ national-accounts-statistics/national-income-reports. Accessed 28 Jan 2015

Chapagain AK, Hoekstra AY (2003) Virtual water flows between nations in relation to trade in livestock and livestock products. Value of Water Research Report Series No. 13. Delft, The Netherlands: UNESCO-IHE

Chapagain AK, Hoekstra AY (2004) Water footprints of nations, Value of Water Research Report No. 16. Delft, the Netherlands: UNESCO-IHE

Chapagain AK, Hoekstra AY (2011) The blue, green and grey water footprint of rice from production and consumption perspectives. Ecol Econ 70:749-758

CIA The World Factbook (2015). https://www.cia.gov/library/pub lications/the-world-factbook/fields/2090.html\#ae. Accessed 30 Jan 2017

Close L (2016) More water restrictions meet more options, with drought-driven water issues on the rise, refineries find new ways to overcome the challenges. http://www.burnsmcd.com/insights news/insights/tech-briefs/2016-issue-1/more-water-restrictionsmeet-more-options. Accessed 15 Nov 2016
COFACE for safer trade (2015) Middle East and North Africa Region: what progress after the "Arab Spring"? http://www. coface.com.au/News-Economic-Studies/News/Middle-East-andNorth-Africa-region-What-progress-after-the-Arab-Spring. Accessed 6 Apr 2015

Construction Review Online (2016) A major desalination plant in Egypt to be constructed. http://constructionreviewonline.com/ 2016/06/egypt-set-to-construct-a-98-6m-desalination-plant/. Accessed 13 Nov 2016

Dong $\mathrm{H}$ et al (2013) Regional water footprint evaluation in China: a case of Liaoning. Sci Total Environ 442:215-224

Doss M, Milne G (2001) Water as an economic good, an approach to the Egyptian economy. http://users.ictp.it/ eee/files/Doss.pdf. Accessed 18 Jan 2015

Durham LS (2005) The elephant of all elephants, prepared for AAPG. https://archives.aapg.org/explorer/2005/01jan/ghawar.cfm. Accessed 1 Sept 2010

Economy Watch (2010). http://www.economywatch.com/world-indus tries/major-industry.html. Accessed 8 Aug 2010

EconStats (1997-2006). http://www.econstats.com/wdi/wdiv_346. htm. Accessed 30 Jan 2017

Egypt National Action Program to Combat Desertification (2005). http://3w.xjlas.ac.cn:81/UploadFiles/20149/201491118452.pdf. Accessed 12 Nov 2016

Eid S et al (2014) Arab Republic of Egypt Ministry of Finance, The Financial Monthly August 2014, Volume 9, No, 10. http://www. mof.gov.eg/MOFGallerySource/English/Reports/monthly/2014/ August2014/Full\%20version.pdf. Accessed 1 Feb 2015

Encyclopedia Britannica Almanac (2010). https://books.google.jo/ books?id=kd2bAAAAQBAJ\&printsec $=$ frontcover\&dq=encyclo pedia + britannica + almanac $+2010 \& h l=e n \& s a=X \& v e d=0 a h U$ KEwjQvt_NjNHSAhVLvxQKHXyhBA0Q6AEIHTAB\#v=one page \&q=encyclopedia\%20britannica\%20almanac\%202010\&f= false. Accessed 12 Mar 2013

Ercin AE, Aldaya MM, Hoekstra AY (2012) The water footprint of soy milk and soy burger and equivalent animal products. Ecol Ind 18:392-402

European Union (2016). https://europa.eu/european-union/about-eu/ countries_en. Accessed 18 Nov 2016

Evans JP (2010) Global warming impact on the dominant precipitation processes in the Middle East. Theor Appl Climatol 99:389-402

Ezz Al Arab M (2015) Egypt has a water problem, international policy digest. http://intpolicydigest.org/2015/08/22/egypt-has-awater-problem/. Accessed 9 Nov 2016

FAO (2003). http://www.fao.org/docrep/005/y4473e/y4473e06.htm. Accessed 7 Jan 2015

FAO AQUASTAT (2000-2014). http://www.fao.org/nr/water/aqua stat/data/query/index.html. Accessed 7 Jan 2015

Fertilizer Statistical Yearbook (2011) (Arab Fertilizer Association). http://www.afa.com.eg. Accessed 20 Mar 2014

Gad A, Ali RR (2009) Water rationalization in Egypt from the perspective of the virtual water concept. In: El Moujabber M, Mandi L, Trisorio-Liuzzi G, Martín I, Rabi A, Rodríguez R (eds) Technological perspectives for rational use of water resources in the Mediterranean region. CIHEAM, Bari, pp 301-310 (Options Méditerranéennes: Série A. Séminaires Méditerranéens; n. 88). http://ressources.ciheam.org/om/pdf/a88/00801205.pdf. Accessed 7 Jan 2011

GCC Gulf Petrochemicals \& Chemicals Association, Petrochemicals \& Chemicals Industry, Facts \& Figures (2012). http://www.gpca. org.ae/adminpanel/pdf/ff12e.pdf. Accessed 12 Feb 2015

General Authority for Statistics, Kingdom of Saudi Arabia (2011). https://www.stats.gov.sa/en/823. Accessed 13 Feb 2015

Gerbens-Leenes W, Hoekstra AY (2012) The water footprint of sweeteners and bio-ethanol. Environ Int 40:202-211 
Gonçalves C et al (2009) Biological treatment of olive mill wastewater by non-conventional yeasts. Bioresour Technol 100:3759-3763

Guan D, Hubacek K (2007) Assessment of regional trade and virtual water flows in China. Ecol Econ 61:159-170

GWI-DesalData $(2013,2015)$. http://desaldata.com/. Accessed 1 Feb 2017

Hamdan O (2009) Integrated waste management for the olive oil pressing industries in Lebanon. http://ec.europa.eu/DocsRoom/ documents/6461/attachments/1/translations/en/renditions/pdf. Accessed 6 Jan 2010

Hamdi M, Garcia JL, Ellouz R (1992) Integrated biological process for olive mill wastewater treatment. Bioprocess Eng 8:79-84

Hanasaki N et al (2010) An estimation of global virtual water flow and sources of water withdrawal for major crops and livestock products using a global hydrological model. J Hydrol 384:232-244

Hardcastle JL (2016) GE helps indiana steel mill save \$210,000, reuse water, reduce waste, environmental leader. http://www.environ mentalleader.com/2016/11/10/ge-helps-indiana-steel-mill-save210000-reuse-water-reduce-waste/. Accessed 15 Nov 2016

Hardisty PE (2010) Environmental and economic sustainability, 1st edn. CRC Press Taylor and Francis Group, LLC, Florida

Hirayama A et al (2002) Omani oil fields produced water: treatment and utilization, society of petroleum engineers (SPE-74413-MS). This paper was prepared for presentation at the SPE International Petroleum Conference and Exhibition in Mexico held in Villahermosa, Mexico, 10-12 February 2002

Hoekstra AY (ed) (2003) Virtual water trade: Proceedings of the International Expert Meeting on Virtual Water Trade. Delft, The Netherlands, 12-13 December 2002, Value of Water Research Report Series No. 12, UNESCO-IHE, Delft, The Netherlands. http://www.waterfootprint.org/Reports/Report12.pdf. Accessed 12 Feb 2008

Hoekstra AY, Hung PQ (2002) Virtual water trade: a quantification of virtual water flows between nations in relation to international crop trade. Value of Water Research Report Series No. 11. Delft, the Netherlands: UNESCO-IHE

Hoekstra AY, Mekonnen MM (2012) The water footprint of humanity. PNAS 109(9):3232-3237

Hoekstra AY et al (2011) The water footprint assessment manual: setting the global standard. Earthscan London, Washington

Hong SM (2004) Water Resources in the Middle East: Conflict and Management. International Symposium of KAMES, PUFS, Pusan Korea, 15-17 October. http://hopia.net/kime/Water\% 20Resources.doc. Accessed 29 Aug 2014

Hydrocarbon Processing (2016) Canadian oil refinery to re-use $100 \%$ of water with GE's wastewater treatment technology. http:// www.hydrocarbonprocessing.com/news/2016/08/canadian-oilrefinery-to-re-use-100-of-water-with-ge-s-wastewater-treatmenttechnology. Accessed Nov 2016

International Olive Council (2006a) Morocco Macroeconomic and Agricultural Indicators. http://www.internationaloliveoil.org/ documents/viewfile/4037-morocco-eng. Accessed 18 Jan 2013

International Olive Council (2006b), Tunisia Macroeconomic and Agricultural Indicators. http://www.internationaloliveoil.org/ documents/viewfile/4045-tunisia-eng. Accessed 12 Jan 2013

Istaitieh A, Hugo S, Husain N (2007) Dubai Chamber of Commerce \& Industry. Macroeconomic Report Series. UAE Macroeconomic Report, http://www.arabruleoflaw.org/compendium/Files/ UAE/103.pdf. Accessed 2 Feb 2015

Jefferies D et al (2012) Water footprint and life cycle assessment as approaches to assess potential impacts of products on water consumption. Key learning points from pilot studies on tea and margarine. J Clean Prod 33:155-166
Jordan Ministry of Water and Irrigation (JMWI), (2013) Jordan Water Sector Facts and Figures 2013. http://www.waj.gov.jo/sites/enus/Hot $\% 20$ Issues/Jordan $\% 20$ Water $\% 20$ Sector $\% 20$ Facts $\% 20$ and \%20Figures.pdf. Accessed 13 Nov 2016

Jordan Valley Authority (2014). http://www.jva.gov.jo/sites/en-us/RSDS/ SiteAssets/rsds\%20phase1.aspx?PageView=Shared. Accessed 13 Nov 2016

Karablieh E (2012) US AID Jordan, Institutional Support \& Strengthening Program. Water valuation study: disaggregated economic value of water in industry and irrigated agriculture in Jordan, October 2012. https://www.researchgate.net/publication/ 302994543_Water_Valuation_Study_Disaggregated_Economic_ Value_of_Water_in_Industry_and_Irrigated_Agriculture_in_Jor dan. Accessed 6 Feb 2015

Khedr A (2006) Universität der Bundeswehr München- Institut für Wasserwesen Mitteilungen Heft 94/2006- Socio-Economic Assessment of Water Supply in Rural Egypt (El-Gharbia Governorate, Saft Torab Case), Oldenbourg Industrieverlag $\mathrm{GmbH}$, München

Kleyn G (2012) Water-shortage crisis escalating in the TigrisEuphrates Basin (Future Directions International). http://www. futuredirections.org.au/publications/food-and-water-crises/678water-shortage-crisis-escalating-in-the-tigris-euphrates-basin.html. Accessed 10 Jan 2015

Kuwait National Petroleum Company (KNPC) Annual Report 2006/2007. http://www.knpc.com.kw/en/MediaCentre/Pages/ Publications.aspx. Accessed 18 Jan 2013

Kundzewicz ZW et al (2007) Freshwater resources and their management. In: Parry ML, Canziani OF, Palutikof JP, van der Linden PJ, Hanson CE (eds) Climate change 2007: impacts, adaptation and vulnerability. Contribution of Working Group II to the Fourth Assessment Report of the Intergovernmental Panel on Climate Change. Cambridge University Press, Cambridge, pp 173-210

Lane T (2014) Desertification: land degradation under a changing climate, climatica. http://climatica.org.uk/desertification-landdegradation-changing-climate. Accessed 11 Nov 2016

Laor Y, Raviv M, Capua SH (2007) The Israeli olive oil industry and viable solutions for its associated wastes. In: Proceeding of the International Conference on New Technologies for the Treatment and Valorization of Agro By-Products, October 3-5, Terni, Italy

Living water (2016) Al Khafji Solar SWRO desalination plant largest in world. https://www.living-water.co.uk/blog/al-khafji-solarswro-desalination-plant-largest-world/. Accessed 13 Nov 2016

Mekonnen MM, Hoekstra AY (2012a) The blue water footprint of electricity from hydropower. Hydrol Earth Syst Sci 16:179-187

Mekonnen MM, Hoekstra AY (2012b) A global assessment of the water footprint of farm animal products. Ecosystems 15:401-415

Michel D et al (2012) Water challenges and cooperative response in the Middle East and North Africa. http://www.stimson.org/ summaries/water-challenges-and-cooperative-response-in-the-mid dle-east-and-north-africa/. Accessed 7 Jan 2015

Mobbs PM (2005a) USGS Minerals Yearbook. The Mineral Industry of Iran. http://www.parstimes.com/library/mineral_industry_ 2005.pdf. Accessed 5 Jan 2011

Mobbs PM (2005b) USGS Minerals Yearbook. The Mineral Industry of Tunisia. https://minerals.usgs.gov/minerals/pubs/country/ 2005/tsmyb05.pdf. Accessed 15 Aug 2010

Mohsen MS, Jaber JO (2002) Potential of industrial wastewater reuse. Desalination 152(1-3):281-289

Mosbrugger V (2008) Climate change and water cycle-some lessons from the geological past. In: Zeirini F, Hötzl H (eds) Climatic changes and water resources in the Middle East and North Africa. Springer-Verlag, Berlin, pp 3-13 
Niaounakis M, Halvadakis CP (2006) Olive processing waste management literature review and patent survey, 2nd edn. Elsevier, United Kingdom

Niccolucci V et al (2011) The real water consumption behind drinking water: the case of Italy. J Environ Manag 92:2611-2618

Novo P, Garrido A, Varela-Ortega C (2009) Are virtual water "flows" in Spanish grain trade consistent with relative water scarcity? Ecol Econ 68:1454-1464

Nwanyanwu CE, Abu GO (2010) In vitro effects of petroleum refinery wastewater on dehydrogenase activity in marine bacterial strains. Ambi-Agua Taubaté 5(2):21-29

Obire O, Amusan FO (2003) The environmental impact of oilfield formation water on a freshwater stream in Nigeria. J Appl Sci Environ Manag 7(1):61-66

Oki T et al (2003) Virtual water trade to Japan and in the world. In: Hoekstra AY (ed) Virtual water trade: Proceedings of the International Expert Meeting on Virtual Water Trade, Value of water Research Report Series No. 12. Delft, the Netherlands: UNESCO-IHE, pp 221-235

Oman Energy Policy, Laws and Regulations Handbook (2015) Volume1 strategic information and basic laws. International Business Publications, USA

OPEC (Organization of the Petroleum Exporting Countries), Annual Statistical Bulletin (2013). http://www.opec.org/opec_web/sta tic_files_project/media/downloads/publications/ASB2013.pdf. Accessed 19 Jan 2015

Organisation mondiale de la Santé (1983) Le problèmes de santé posés par la réutilisation des effluents traités, Rapport sur une réunion de l'OMS, Alger, ler-5 juin 1980 (in French)

Pollution Prevention and Abatement Handbook, World Bank Group (1998)

Pollution Prevention in the Textile Industry within the Mediterranean region, Regional Activity Center for Cleaner Production (RAC/ CP) (2002)

Porkka M (2011) The role of virtual water trade in physical water scarcity: Case Central Asia. AALTO University, school of Engineering, Department of Civil and Environmental Engineering. http://www.wdrg.fi/wp-content/uploads/2011/12/porkka 2011 diplomityo.pdf. Accessed 16 Nov 2016

Radhouane L (2013) Climate change impacts on North African countries and on some Tunisian economic sectors. J Agric Environ Int Dev JAEID 107(1):101-113

Ragab R, Prudhomme C (2000) Climate change and water resources management in the southern Mediterranean and Middle East countries. The Second World Water Forum. The Hague. March, $17-22$

Rajesh D et al (2009) Impact assessment of soils treated with refinery effluent. Eur J Soil Biol 45(5):459-465

Rao CP (2010) Challenges and opportunities for international marketers in Kuwait. In: Singh S (ed) Handbook of business practices and growth in emerging markets. World Scientific Publishing Co. Pte. Ltd, Singapore, pp 385-418

Roson R, Sartori M (2010) Water scarcity and virtual water trade in the Mediterranean. Working Paper n. 38. http://www.iefe. unibocconi.it/wps/wcm/connect/e7e2db804cadae0292ebfe0f7bd c7be0/WP+Roson-Sartori+Water+Scarcity.pdf?MOD=AJPER ES\&useDefaultText $=0$ \&useDefaultDesc $=0$. Accessed 16 Nov 2016

Ruini L et al (2013) Water footprint of a large-sized food company: the case of Barilla pasta production. Water resources and industry $1-2: 7-24$

Saudi Industrial Development Fund. Marketing Consultancy Division. Export Consultancy Unit (ECU) (2012) Country Profile (Update), Hashemite Kingdom of Jordan. http://www.sidf.gov. sa/en/MediaCenter/ResearchandStudies/ExportInformation
CountryProfileArchive/2012-CP-Jordan-Update.pdf. Accessed 12 Feb 2015

Schmidt A, Knobloch M (2000) Olive oil-mill residues: the demonstration of an innovative system to treat wastewater and to make use of generated bioenergy and solid remainder. In: Proceedings of the 1 st World Conference on Biomass for Energy and Industry, Seville, 5-9 June 2000, pp 452-454

Shaikh Al-Deen A, El-Kholy O (2001) Industry and sustainable development in the Arab region, Arabian Gulf University-UNEP regional office for west Asia

SMEToolkit (2013) Build your business-Algeria overview. http:// www.smetoolkit.org/smetoolkit/en/content/en/7419/AlgeriaOverview. Accessed 8 Apr 2015

Spanish Ministry of Environment (2000) Ministry of Environment Spain, Pollution prevention in Olive oil production, Regional Activity Centre for Cleaner Production (RAC/CP) Mediterranean Action Plan. http://www.industry.org.il/_UploadsCl/dbsAttached Files/oliveoilproduction(1).pdf. Accessed 16 Nov 2016

Taib M (2012) USGS minerals yearbook. The mineral industry of Qatar, https://minerals.usgs.gov/minerals/pubs/country/2012/myb32012-qa.pdf. Accessed 12 Feb 2015

The Arabic Network for Human Rights Information (2007). http:// www.anhri.net/syria/cdf/2007/pr0611.shtml. Accessed $18 \mathrm{Sept}$ 2010 (in Arabic)

The Logistics Sector on the Southern Shores of the Western Mediterranean (2010) Assessment and proposals for improving the provision of logistics services. Case of the Maghrebian Countries: Algeria, Libya, Mauritania, Morocco and Tunisia. http://www.cetmo.org/pdf/Logistic\%20Study\%20on\%20the $\% 20$ southern\%20shores.pdf. Accessed 31 Jan 2015

The Oil Drum (2009) Produced water, GOSPs and Saudi Arabia. http://www.theoildrum.com/node/6052. Accessed 19 Jan 2017

The Report: Emerging Algeria (2008) Oxford Business Group

The Report: Emerging Jordan (2007) Oxford Business Group

UN comtrade database (2009-2015). http://comtrade.un.org/db/. Accessed 2 Dec 2012

UN data A World of Information (1995). http://data.un.org/Data. aspx?d=SNAAMA\&f=grID $\% 3 \mathrm{~A} 101 \% 3 \mathrm{BcurrID} \% 3 \mathrm{AUSD} \% 3 \mathrm{Bpc}$ Flag\%3A1. Accessed 7 Feb 2015

UN data A World of Information (2008). http://data.un.org/Data. aspx? $\mathrm{d}=\mathrm{UNIDO} \& \mathrm{f}=$ tableCode $\% 3 \mathrm{~A} 20 \% 3 \mathrm{BisicCode} \% 3 \mathrm{~A} 2710$. Accessed 4 Feb 2015

UN data A World of Information (2007-2010). http://data.un.org/ Data.aspx $\mathrm{q}=$ fertilizers \pm and \pm nitrogen \pm compounds $\& \mathrm{~d}=\mathrm{UNI}$ DO\&f=tableCode\%3a20\%3bisicCode\%3a2412. Accessed 6 Feb 2015

UN data A world of information (2010). http://data.un.org/Data. aspx $? \mathrm{~d}=\mathrm{UNIDO} \& \mathrm{f}=\mathrm{tableCode} \% 3 \mathrm{~A} 20 \% 3 \mathrm{BisicCode} \% 3 \mathrm{~A} 2320$. Accessed 29 Jan 2015

United Nations Convention to Combat Desertification (UNCCD) (2014) Desertification the invisible frontline. http://www.unccd. int/Lists/SiteDocumentLibrary/Publications/Desertification_The\% 20invisible_frontline.pdf. Accessed 11 No 2016

US Energy Information Administration (USEIA) (2011). http://www. eia.doe.gov/. Accessed 2 Dec 2012

Van Oel PR, Hoekstra AY (2012) Towards quantification of the water footprint of paper: a first estimate of its consumptive component. Water Resour Manag 26:733-749

Van Oel PR, Mekonnen MM, Hoekstra AY (2009) The external water footprint of the Netherlands: geographically-explicit quantification and impact assessment. Ecol Econ 69:82-92

Vanham D, Bidoglio GA (2013) Review on the indicator water footprint for the EU28. Ecol Ind 26:61-75

Velázquez E (2007) Water trade in Andalusia. Virtual water: an alternative way to manage water use. Ecol Econ 63:201-208 
Verma S et al (2009) Going against the flow: a critical analysis of inter-state virtual water trade in the context of India's National River Linking Program. Phys Chem Earth 34:261-269

Wang LK et al (2004) Handbook of Industrial and hazardous wastes treatment, 2nd edn. Marcel Dekker Inc., New York, Basel

Wickström L (2010) Islam and water: Islamic guiding principles on water management. In: Luomi M (ed.) Managing blue gold: new perspectives on water security in the Levantine Middle East, Helsinki, The Finnish Institute of International Affairs, FIIA Report, 25, pp. 98-109. https://www.files.ethz.ch/isn/124603/ UPI_FIIA_25_Luomi_web_8_chapters.pdf. Accessed 13 Jan 2015

World Bank (2007) Making the most of scarcity: Accountability for better water management results in the Middle East and North Africa. Washington, DC. http://siteresources.worldbank.org/ INTMNAREGTOPWATRES/Resources/Making_the_Most_of_ Scarcity.pdf. Accessed 12 Nov 2016

World Bank (2012) Renewable energy desalination: an emerging solution to close Middle East and North Africa's Water Gap. http://siteresources.worldbank.org/INTMNAREGTOPWATRES/ Resources/Desal_An_Emerging_Solution_to_Close_MENAs_ Water_Gap.pdf. Accessed 14 Nov 2016

World bank data on total population (1995-2015). http://data. worldbank.org/indicator/SP.POP.TOTL. Accessed 20 Mar 2015

World Bank Database (2005-2013). http://data.worldbank.org/indica tor/NY.GDP.MKTP.CD. Accessed 20 Feb 2015

World Bank Database (2009-2015). http://wits.worldbank.org/Coun tryProfile/Country/BHR/Year/2011/Summarytext. Accessed 21 Feb 2015
World Bank2 (2017). http://www.worldbank.org/en/region/mena. Accessed 16 Nov 2016

World Bank3 (2015). http://data.worldbank.org/indicator/SP.POP. GROW?locations=ZQ. Accessed 20 Nov 2016

Yager TR (2005) USGS minerals yearbook. The mineral industry of Israel. http://minerals.usgs.gov/minerals/pubs/country/2005/ ismyb05.pdf. Accessed 12 Sept 2010

Yeşilada Ö, Şik S, Şam M (1999) Treatment of olive oil mill wastewater with fungi. Turk J Biol 23:231-240

Zeitoun M, Allan JA, Mohieldeen Y (2010) Virtual water 'flows' of the Nile Basin, 1998-2004: a first approximation and implications for water security. Glob Environ Change 20:229-242

Zereini F, Hötzl H (2008) Climatic changes and water resources in the Middle East and North Africa. Springer-Verlag, Berlin

Zhang Z, Yang H, Shi M (2011) Analyses of water footprint of Beijing in an interregional input-output framework. Ecol Econ 70:2494-2502

Zhan-Ming C, Chen GQ (2013) Virtual water accounting for the globalized world economy: national water footprint and international virtual water trade. Ecol Ind 28:142-149

Zimmer D, Renault D (2003) Virtual water in food production and global trade: review of methodological issues and preliminary results. In: Hoekstra AY (ed) Virtual water trade: proceedings of the International Expert Meeting on Virtual Water Trade, Value of Water Research Report Series No. 12. Delft, the Netherlands: UNESCO-IHE, pp 93-109 